\title{
The Relationship between Environmental Temperature and Sleep Needs of Patients in Emergency Hospitals
}

\author{
Nova Budiharjo ${ }^{1}$, Sismulyanto ${ }^{2}$, Menap $^{2}$, Harry Kuswandari ${ }^{3}$, OvieLestya Nurdiana $^{1}$, Mursaka $^{1}$, \\ Yahya Ulumuddin ${ }^{1}$ \\ ${ }^{1}$ Postgraduate Student, ${ }^{2}$ Graduate School, Public Health Department, Universitas Qomarul Huda Badaruddin \\ Bagu, West Nusa Tenggara, Indonesia, ${ }^{3}$ Nurse at the Regional General Hospital of North Lombok Regency, West \\ Nusa Tenggara, Indonesia
}

\begin{abstract}
Sleep is one of the basic human needs. Patients who are sick often need more sleep and rest than healthy people. Inadequate sleep and poor sleep quality can result in disturbed physiological and psychological balance. One of the factors that can affect the quality and quantity of sleep is the ambient temperature. The purpose of this study was to determine the relationship between environmental temperature and the fulfillment of the sleep needs of patients in the inpatient room. This type of research is an analytic survey with a cross-sectional design. The population in this study were all inpatients class III North Lombok Regency Emergency Hospital. The sampling technique used accidental sampling with a sample size of 71 people. Data analysis using Chi-Square. The results showed that the environmental temperature of the North Lombok Emergency Hospital was in the high category, namely 53.5\%. Most of the patients' sleep needs were in the insufficient category, namely $67.6 \%$. There is a relationship between ambient temperature and the need for the sleep of patients in the Emergency Hospital of North Lombok Regency with an X2 value of 34.054 with a $p$-value of $0.000(p<0.05)$. The conclusion in this study is that the environmental temperature affects the patient's sleep needs, where the higher the ambient temperature, the patient's need for sleep becomes disturbed or insufficient. Suggestions in this study can provide a reference in improving service to patients, especially increasing the patient's sleep needs such as facilities and infrastructure (air conditioning and ventilation) so that the room temperature is not hot.
\end{abstract}

Keywords: Environmental Temperature, Sleep Needs, emergency hospital, nurse

\section{Introduction}

Inadequate sleep and poor sleep quality can result in disturbed physiological and psychological balance. Physiological effects include a decrease in daily activities, feeling weak, a slow healing process, decreased immune system, and instability of vital signs. Meanwhile, the

\section{Corresponding Author:}

\section{Nova Budiharjo}

Postgraduate student, Universitas Qomarul Huda

BadaruddinBagu, H. Badaruddin-Bagu Street, Central

Lombok, Pringgarata, West Nusa Tenggara, Indonesia

Email: novabudiharjo@gmail.com

Phone number: +62813-3860-7899 psychological impact includes depression, anxiety, and lack of concentration ${ }^{(1)}$. According to Nurlela ${ }^{(1)}$, people who are sick need rest and sleep more than when they are normal because the body is working hard to provide energy for recovery, but many aspects of the disease also make it difficult to meet their sleep and rest needs. The need for sleep is essential to everyone's quality of life. Each individual has different sleep needs in quality and quantity. The quality and quantity of sleep are influenced by several factors that can indicate an individual's ability to sleep and get the amount of sleep according to his needs. Factors that can affect the quality and quantity of sleep include illness, environment, fatigue, lifestyle, anxiety level, motivation, and drugs ${ }^{(2)}$. 
Hospital is a health service institution that provides complete individual health services that provide inpatient, outpatient, and emergency services. The hospital also provides options for some of its residences, which cater to the upper-middle class to the lower middle class ${ }^{(3)}$. The hospital strives to provide equitable health services for everyone without forgetting its social function. The quality of service in a hospital can be improved if it is supported by an increase in the quality of environmental care facilities. Inpatient rooms are a form of care facilities that are important for patient care. Inpatient is a term which means the process of patient care by health professionals due to certain diseases, where the patient is confined to a room in the hospital, if the patient requires treatment in the hospital or is staying in the hospital, middle-aged people who sleep too little or too much turns out to be more likely to experience cognitive decline and experience longer treatment.

The environmental condition of the inpatient room also affects the patient's psychology, because the patient being treated is very sensitive to environmental stimuli. If the inpatient room is noisy, the air temperature is too hot or too cold, poor lighting, cleanliness, and tidiness are not maintained, it will indirectly interfere with the patient's comfort to rest, thus prolonging the treatment process. The inpatient room should generate optimism so that it can help the patient's healing process. The environment in which a person sleeps affects the ability to fall asleep. Good ventilation provides comfort for restful sleep. The size, hardness, and position of the bed affect the quality of a person's sleep. Light levels, temperature, and sound can affect the ability to sleep. Some patients prefer to sleep with the lights turned off, dimmed, or kept on. Hot or cold temperatures cause the client to experience anxiety. Some people like quiet conditions for sleeping and some like sounds to help sleep such as soft music and television ${ }^{(4)}$.

One of the causes of an uncomfortable environment is natural disasters, and one of them is an earthquake. Indonesia has a large area with many islands, located in the path of earthquakes and volcanoes. This condition makes it prone to various natural disasters. There are dangers posed, which can threaten life safety, natural damage, and environmental destruction in the event of a disaster. The impacts are in the form of casualties, property, damage to infrastructure, social environment, and disruption to the life and livelihoods of the community that has been previously establishedLidstone ${ }^{(5)}$.

One of the causes of an uncomfortable environment is natural disasters, and one of them is an earthquake ${ }^{(6)}$. Indonesia has a large area with many islands, located in the path of earthquakes and volcanoes. This condition makes it prone to various natural disasters. Some dangers can be caused, which can threaten life safety, natural damage, and environmental destruction if an earthquake occurs. The earthquake that hit Lombok caused many casualties in North Lombok Regency, the environment, and damaged office and hospital infrastructure. The Regional General Hospital of North Lombok Regency suffered $80 \%$ damage due to the Lombok, NTB earthquake on Sunday, August 5, 2018. The earthquake measuring 7 on the Richter scale destroyed all hospital facilities so that the room for patient services could not be used. Due to the destruction of hospital facilities, services were carried out at the emergency hospital.

Most of the hospitalized patients are at high risk of experiencing disturbed sleep patterns due to various factors. That sleep disturbance affects $45 \%$ of people aged 50 years and over and $68 \%$ of people who live in long-term care facilities. In the sentence above, it can be concluded that patients who experience sleep disorders are more prone to occur in hospitals, especially inpatient rooms.Based on the results of a preliminary study at the North Lombok Emergency Hospital, patient data after the earthquake decreased inpatients, before the earthquake the average monthly hospitalization reached 150-200 patients, while after the earthquake the average monthly patient was 85 patients. Inpatient services are carried out at the Emergency Hospital. The results of interviews with 10 patients found that all patients (10 people) could not sleep because of the hot weather and uncomfortable environment, while the temperature in the inpatient room of the Emergency Hospital was more than $25 \cdot \mathrm{c}-30 \cdot \mathrm{c}$ during the day and at night the weather is cold with temperatures ranging from $16 \cdot c-20 \cdot c$. The purpose of this study was to determine the relationship between environmental temperature and the fulfillment of sleep needs in the inpatient room of the North Lombok 
District Emergency Hospital.

\section{Method}

This type of research is an analytical survey. The subjects in this study were 71 inpatients at the North Lombok Emergency Hospital. The independent variable in this study is ambient temperature. The dependent variable in this study is the need for sleep. The instrument used was in the form of a standardized questionnaire adopted by the Sleep Quality Questionnaire which was compiled based on 7 (seven) parameters modified from the PSQI questionnaire consisting of 19 questions. This questionnaire was modified based on the patient's needs with a rating range of $0-3$. The number of questionnaires was 7 items and there were additions at the end of the questionnaire questions about the patient's perception of "self-report" in general about good or bad sleep quality. Validity and reliability test using Cronbach alpha. The validity test results obtained a value of 0.83-0.96 and the reliability test results obtained a value of 0.89 which indicates that this instrument is valid and reliable, so it can be used as a research instrument. Data analysis using chi-square.

\section{Result}

\section{Univariate Analysis}

Table 1 Frequency Distribution Based on Patient Characteristics

\begin{tabular}{|c|c|}
\hline Gender & $F(\%)$ \\
\hline Male & $37(52.1)$ \\
\hline Female & $34(47.9)$ \\
\hline Total & $71(100.0)$ \\
\hline Age & $F(\%)$ \\
\hline $17-25$ year & $7(5.9)$ \\
\hline $26-35$ year & $16(22.5)$ \\
\hline $36-45$ year & $16(22.5)$ \\
\hline $46-55$ year & $12(16.9)$ \\
\hline $56-65$ year & $12(16.9)$ \\
\hline$>65$ year & $8(11.3)$ \\
\hline Total & $71(100.0)$ \\
\hline
\end{tabular}

Based on the table above, it was found that the sex of male patients was $37(52.1 \%)$ patients while female patients were 34 (47.9\%) patients. Most of the patients aged 26-35 years and 36-45 years were $16(22.5 \%)$, while the lowest was 17-25 years old as many as 7 $(5.9 \%)$ patients. 
Table 2 Frequency Distribution of Environmental Temperature

\begin{tabular}{|c|c|}
\hline Environmental Temperature & Frequency(\%) \\
\hline $\operatorname{High}(>24 o C)$ & $38(53.5)$ \\
\hline Normal (22 oC-24oC) & $16(22.5)$ \\
\hline Low $(<22$ oC $)$ & $17(23.9)$ \\
\hline Total & $71(100.0)$ \\
\hline Sleep Needs & Frequency $(\%)$ \\
\hline Enough & $23(32.4)$ \\
\hline Less & $48(67.6)$ \\
\hline Total & $71(100.0)$ \\
\hline Sleep Quality & Frequency $(\%)$ \\
\hline Good & $20(28.2)$ \\
\hline Bad & $51(71.8)$ \\
\hline Total & $71(100.0)$ \\
\hline
\end{tabular}

Based on table 2 above, it is found that the frequency distribution of the environmental temperature is mostly in the high category $(>24 \mathrm{oC})$, namely $38(53.5 \%)$ while the lowest is $17(23.9 \%)$ with normal ambient temperature $(22 \mathrm{oC}-24 \mathrm{oC})$ totaling $165 \%)$. The frequency distribution of the patient's sleep needs was found to be sufficient category by $23(32.4 \%)$ while less for $48(67.6 \%)$ patients. The frequency distribution of the sleep quality of patients in the good category was $20(28.2 \%)$ while $51(71.8 \%)$ patients were bad.

\section{Bivariate Analysis}

Table 3: Cross Tabulation and Chi-Square Test between Environmental Temperature and Patient Sleep Needs

\begin{tabular}{|c|c|c|c|c|c|c|c|c|}
\hline \multirow{3}{*}{ Temperature } & \multicolumn{6}{|c|}{ Sleep needs } & \multirow{3}{*}{$\begin{array}{c}P \\
\text { value }\end{array}$} & \multirow{3}{*}{$\mathbf{X} 2$} \\
\hline & \multicolumn{2}{|c|}{ Enough } & \multicolumn{2}{|c|}{ Less } & \multicolumn{2}{|c|}{ Total } & & \\
\hline & $\mathbf{N}$ & $\%$ & $\mathbf{n}$ & $\%$ & $\mathbf{n}$ & $\%$ & & \\
\hline High & 1 & 1.4 & 37 & 52.1 & 38 & 53.5 & \multirow{4}{*}{0.000} & \multirow{4}{*}{34.054} \\
\hline Normal & 12 & 16.9 & 4 & 5.6 & 16 & 22.5 & & \\
\hline Low & 10 & 14.1 & 7 & 9.8 & 17 & 23.9 & & \\
\hline Total & 23 & 32.4 & 48 & 67.6 & 71 & 100.0 & & \\
\hline
\end{tabular}


Based on table 3, cross-tabulation between ambient temperature and sleep needs, it was found that $38(53.5 \%)$ patients with high temperature had enough sleep needs as much as $1(1.4 \%)$ patients and fewer sleep needs as many as $37(52.1 \%)$ patients, $16(22.5 \%)$ patients with normal ambient temperature had sufficient sleep needs for $12(16.5 \%)$ patients and less than 4 (5.6\%) patients, while $17(23.9 \%)$ patients had a low ambient temperature. by having adequate sleep needs as many as $10(14.1 \%)$ patients and less as many as $7(9.8 \%)$ patients. The results of statistical tests using chi-square obtained a value of X234,054 with a p-value of 0,000 ( $<<0.05)$, meaning that there is a relationship between ambient temperature and sleep needs of patients in the North Lombok District Emergency Hospital.

\section{Discussion}

The need for sleep is critical to the quality of life of all patients. Each individual has different sleep needs in quality and quantity. Also, the quality and quantity of sleep are influenced by several factors that can indicate an individual's ability to sleep and get the amount of sleep according to his needs. Factors that can affect the quality and quantity of sleep include illness, environment, fatigue, lifestyle, anxiety level, motivation, and drugs. The physical environment in which a patient sleeps is very important in the ability to fall asleep and stay asleep. Uncomfortable bed conditions, non-essential ventilation, noise from roommates, room doors that are frequently opened and closed, footsteps, telephone sounds, lighting that does not fit the bed, and room temperature that is too warm or cold can affect the patient's sleep needs and prolong the recovery process of the sick individual ${ }^{(7)}$.

Based on table 3, cross-tabulation between ambient temperature and sleep needs, it was found that $38(53.5 \%)$ patients with high temperature had enough sleep needs as much as $1(1.4 \%)$ patients and fewer sleep needs as many as $37(52.1 \%)$ patients, 16 (22.5\%) patients with normal ambient temperature had sufficient sleep needs for $12(16.5 \%)$ patients and less than 4 (5.6\%) patients, while 17 (23.9\%) patients had a low ambient temperature. by having adequate sleep needs as many as $10(14.1 \%)$ patients and less as many as $7(9.8 \%)$ patients. The results of statistical tests using the chi-square value obtained X2 34.054 with a p-value of $0.000(p<0.05)$, meaning that there is a relationship between ambient temperature and sleep needs of patients in the North Lombok Emergency Hospital. The results of this study are in line with study, which obtained a p-value of $0.039(p<0.05)$, which means that there is a relationship between the environment and the patient's sleep patterns. It is related to the transfer of heat through radiation consisting between the human body and the walls and objects that surround it, which can absorb or otherwise radiate heat. This result is also in line with Lukman's ${ }^{(2)}$ research, there is a relationship between the comfort of the patient's room and the need for sleep rest of the patient with a p-value of 0.019 .

This research is also in line with Sastrowinoto's theory that most patients are not aware of the comfortable atmosphere in the room. Only when the condition deviates from the limits of comfort will the patient experience discomfort. The feeling of discomfort can vary from annoying to painful, depending on the degree of disturbance from the temperature controller. Too hot can make you tired and drowsy, while too cold makes you uneasy and breaks down your tension. If the problem of temperature comfort is faced with a variety of different temperatures in the room it will be possible to find an economically balanced temperature range. This range is called the zone of vasomotor regulation because a lack of heat is maintained by regulating blood distribution. The temperature range between $22-24^{\circ} \mathrm{c}$ (for tropical countries) is called the comfort zone.

Furthermore, if the temperature rises to beyond the comfortable limit, there will be excess heat and that heat will heat the edges of the body. Sweat will come out to moderate the core temperature, and it is called the zone of evaporation control (zone of evaporation control) Hani Yousef;. The upper limit of this zone is the limit value of heat tolerance, and above this limit, the core temperature will increase which can result in short-term death due to heatstroke. While temperatures below the vasomotor control zone result in a lack of heat, heat loss is more than the rate of heat production by the body. This temperature is called the cooling zone. Initially, the heat loss will only affect the edges of the body which can tolerate a temporary lack of heat. However, if the heat loss or cooling continues, death will occur due to 
freezing.According to Mazkur ${ }^{(8)}$ Hospital is a place for sick patients who are the source of disease transmission. If the temperature is low and the humidity is too high, it will be easier to breed bacteria, fungi, viruses, and various other germs. Thus, if temperature and humidity are not considered properly, it will cause harm to the hospital community.

\section{Conclusion}

Most of the environmental temperature of the North Lombok District Emergency Hospital was in the high category, amounting to $53.5 \%$. Most of the patients' sleep needs were in the insufficient category, namely $67.6 \%$. There is a relationship between ambient temperature and the need for the sleep of patients at the North Lombok District Emergency Hospital.

Acknowledgment: I would like to thank the respondents who participated.

Conflict on Interest: There is no conflict of interest to be declared

\section{Source of Funding: None}

Ethical Clearance: The study was approved by the health research ethics commission

\section{References}

1. Nurlela S, Saryono, Yuniar I. FACTORS AFFECTING SLEEP QUALITY OF LAPARATOMIC POST OPERATION PATIENTS IN INpatient Care Room at PKU MUHAMMADIYAH GOMBONG HOSPITAL. J Ilm Kesehat Keperawatan [Internet]. 2009 Feb 1 [cited 2021 Jan 13];5(1). Available from: http:// ejournal.stikesmuhgombong.ac.id/JIKK/article/ view/6

2. Lukman NA. Factors Related to Fulfillment of Clients' Sleep Rest Needs for Post Operations in the Surgical Care Room of the Makassar Labuang Baji Hospital. [Makassar]: Universitas Islam Negeri Alaudin Makassar; 2013.

3. Mulyanto J, Kringos DS, Kunst AE. Socioeconomic inequalities in healthcare utilisation in Indonesia: A comprehensive survey-based overview [Internet]. Vol. 9, BMJ Open. BMJ Publishing Group; 2019 [cited 2021 Jan 22]. p. 26164. Available from: http://bmjopen.bmj.com/

4. Dijkstra K, Pieterse M, Pruyn A. Physical environmental stimuli that turn healthcare facilities into healing environments through psychologically mediated effects: Systematic review [Internet]. Vol. 56, Journal of Advanced Nursing. John Wiley \& Sons, Ltd; 2006 [cited 2021 Jan 22]. p. 166-81. Available from: https:/onlinelibrary.wiley.com/ doi/full/10.1111/j.1365-2648.2006.03990.x

5. Lidstone J, Dechano LM, Stoltman JP. International Perspectives on Natural Disasters: Occurrence, Mitigation, and Consequences. International Perspectives on Natural Disasters: Occurrence, Mitigation, and Consequences. Netherlands: Springer Netherlands; 2004.

6. Rosselló J, Becken S, Santana-Gallego M. The effects of natural disasters on international tourism: A global analysis. Tour Manag [Internet]. 2020 Aug 1 [cited 2021 Jan 22];79:104080. Available from: /pmc/articles/PMC7115519/?report=abstract

7. Khair YU. Factors Associated with Fulfilling Sleep Needs in Preoperative Patients who were Hospitalized for the First Time in the Surgical Room Dr. M Djamil Padang in 2012 [Internet]. [Padang]: Universitas Andalas; 2012 [cited 2021 Jan 13]. Available from: http://repo.unand. ac.id/632/1/SKRIPSI.pdf

8. Maskur A. The Relationship between the Nursing Environment and Sleep Patterns in Inpatient Cases in the Class III Surgical Room at dr. R. Soedjono Selong, East Lombok Regency. STIKES Mataram; 2017. 